\title{
DETERMINATION OF THE CUTTING-TOOL PERFORMANCE OF HIGH-ALLOYED WHITE CAST IRON (Ni-Hard 4) USING THE TAGUCHI METHOD
}

\author{
DOLOČANJE ZMOGLJIVOSTI REZALNIH ORODIJ NA MOČNO \\ LEGIRANEM BELEM LITEM ŽELEZU (Ni-Hard 4) Z UPORABO \\ TAGUCHI METODE
}

\author{
Durmuş Kir ${ }^{1}$, Hasan Öktem ${ }^{1}$, Mustafa Çöl2 ${ }^{2}$, Funda Gül Koç², Fehmi Erzincanli ${ }^{3}$ \\ ${ }^{1}$ University of Kocaeli, Hereke Vocational School, Kocaeli, Turkey \\ ${ }^{2}$ University of Kocaeli, Faculty of Engineering, Metallurgy and Material Engineering, Kocaeli, Turkey \\ ${ }^{3}$ University of Düzce, Faculty of Engineering, Mechanical Engineering, Düzce, Turkey \\ hoktem@kocaeli.edu.tr \\ Prejem rokopisa - received: 2014-10-22; sprejem za objavo - accepted for publication: 2015-04-09
}

doi: $10.17222 / \mathrm{mit} .2014 .270$

\begin{abstract}
High-alloyed white-cast-iron materials are commonly used in the manufacturing industry due to their high wear resistance. The aim of this research is to determine the cutting tool and the optimum cutting conditions required for the metal cutting of these materials. In this study, it is proposed to determine the wear and the tool life utilizing the Taguchi optimization method when hard turning the Ni-Hard 4 material, the alloyed cast iron, with cutting tools produced with powder metallurgy (PM) and to improve the performance of the cutting tools. A series of 18 experiments were conducted on a CNC turning machine, using the

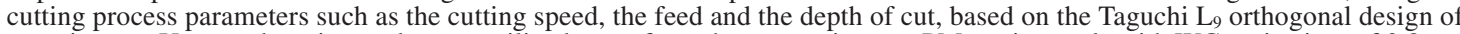
experiments. Uncoated cutting tools were utilized to perform these experiments. PM cutting tools with WC grain sizes of $0.8 \mu \mathrm{m}$ and $1.25 \mu \mathrm{m}$ were selected for the hard-turning experiments. The flank wear of the cutting tools was examined with SEM. Then, the life of each cutting tool was identified based on the cutting length. The performance of the cutting tools in terms of the wear and the tool life was determined with the Taguchi method based on the obtained data. The results of this study contributed to the hard turning of the Ni-Hard 4 material that is mostly employed in the as-cast condition in the manufacturing industry due to its high hardness. The optimum cutting conditions were determined by means of the Taguchi method.

Keywords: hard turning, cutting tools, wear, Taguchi method
\end{abstract}

Močno legirano belo lito železo se uporablja v predelovalni industriji zaradi velike odpornosti proti obrabi. Namen raziskave je poiskati rezalno orodje in optimalne pogoje rezanja, potrebne za rezanje teh materialov. V študiji je predlagano, da se določi obraba in zdržljivost orodij, z uporabo Taguchi metode, optimizacija pri struženju materiala Ni-Hard 4 legiranega litega železa z rezalnimi orodji, izdelanimi po postopku metalurgije prahov (PM), da bi izboljšali zmogljivost rezalnega orodja. Serija 18-ih preizkusov, z uporabo procesnih parametrov, kot so: hitrost rezanja, podajanje in globina reza, na podlagi Taguchi L. ortogonalne postavitve preizkusa, so bile izvršene na CNC stružnici. Za te eksperimente so bila uporabljena rezalna orodja brez prevleke. Za preizkus težkega struženja so bila izbrana PM rezalna orodja, z velikostjo zrn WC med $0.8 \mu \mathrm{m}$ in $1.25 \mu \mathrm{m}$. Obraba boka rezalnega orodja je bila preiskovana s SEM. Zdržljivost vsakega orodja je bila določena na podlagi dolžine struženja. Rezultati študije se nagibajo k težkem struženju materiala Ni-Hard 4, ki se ga večinoma uporablja v predelovalni industriji v litem stanju, zaradi velike trdote. Optimalni pogoji rezanja so bili določeni s pomočjo Taguchi metode.

Ključne besede: težko struženje, rezalna orodja, obraba, Taguchi metoda

\section{INTRODUCTION}

In today's industry, customers expect low costs, short machining times and competitiveness, so the developments in the material science have to involve new and flexible manufacturing technologies. Especially, some mechanical parts used in cement, concrete, machinemanufacturing and ceramic industries are very difficult to machine because of their high hardness. Based on modern technologies ${ }^{1,2}$ such as hard turning, milling and drilling, it is possible to cut high-alloyed cast iron materials. High-alloyed cylindrical cast-iron materials can be machined with different methods. Hard turning is preferred for these kinds of materials due a faster, low-cost and high-quality process. The hard-turning process has advantages like short set-up times, short process steps, a better surface quality, a lower wear rate and a longer tool life. In addition, it is not necessary to use the cutting fluid for alternative metal-cutting methods. ${ }^{3}$ Several studies ${ }^{4-6}$ have been performed to investigate and develop the microstructure and mechanical properties of Ni-Hard 4, so far known as the high-alloyed white-cast iron. Its main alloying elements are 7-11\% Cr, 5-7 \% Ni and 2.5-3.2\% C. Researchers have studied the wear resistance, heat treatments and the influence of the alloying elements on cast iron. ${ }^{4-6}$

The tool wear and the tool life are two important problems encountered in the hard-turning processes. There are many investigations, focused on diminishing these problems. Some of them ${ }^{7-9}$ try to determine the wear rate and the tool life of the AISI 52100, AISI D2 and AISI H11 steel materials during hard turning. Most frequently, experiments were carried out on cubic boron nitride $(\mathrm{CBN})$ tools under various cutting conditions. 
Some other researchers ${ }^{10-12}$ measured the wear on CBN tools and polycrystalline cubic boron nitride (PCBN) tools after the hard turning of the AISI 52100 steel materials. They examined the performances of the cutting tools with respect to the tool life using mathematical models depending on the Taylor rule. In two group studies, the tool wear was investigated with a light microscope and SEM. Lin et al. ${ }^{13}$ and Khrais and Lin ${ }^{14}$ examined the hard turning of the AISI 1040 material by employing uncoated and coated WC-Co tools under wet and dry cutting conditions. They classified the wear mechanisms and types of the WC-Co tools coated with PVD AlTiN and $\mathrm{AlCrN}$ with a light microscope. They also determined the effects of the coatings on the wear and tool life at five different cutting speeds and $V_{\mathrm{Bmax}}=0.6 \mathrm{~mm}$.

Özel et al. ${ }^{15}$ and Arsecularatne et al. ${ }^{16}$ performed experiments to identify the wear, tool life and materialremoval rate when hard turning the AISI D2 steel material with PCBN and ceramic tools under dry conditions. Mathematical models were developed based on the Taylor rule (the formula) to obtain the cutting conditions providing the longest tool life and the largest materialremoval rate. Costes et al. ${ }^{17}$ investigated the machining of the Inconel 718 material, utilizing CBN cutting tools in wet conditions. According to this study, the adhesion and diffusion are the most dominant mechanisms for the wear in different cutting conditions.

Unlike the studies mentioned above, Thamizhmanii and Hasan ${ }^{18}$ and Yiğit et al. ${ }^{19}$ reported about experimental results predicting the tool wear and life during the hard turning of gray and spheroidal graphite cast iron with various cutting tools based on the Taguchi optimization method. Several researchers ${ }^{20-23}$ used the Taguchi method for different materials and cutting tools in the hard-turning process to find the optimum cutting conditions versus the minimum tool wear and to prolong the tool life. Other researchers ${ }^{24,25}$ were focused on the surface roughness, cutting forces and tool wear during the hard turning of high-alloy white cast iron in different cutting conditions, employing CBN inserts. Yücel and Günay ${ }^{26-28}$ conducted investigations on the machinability of the high-alloy white cast-iron material, Ni-Hard 4. They studied the tool wear, tool life, surface roughness and cutting forces during the hard turning with ceramic and CBN tools based on the Taguchi optimization method.

In this study, a total of 18 hard-turning experiments based on the $\mathrm{L}_{9}$ orthogonal array design were performed on the Ni-Hard 4 material, which has a high wear resistance and which is not supposed to be machinable. The as-cast material was turned on a $\mathrm{CNC}$ machine without the cutting fluid. Uncoated cutting tools (WC-Co) with two different grain sizes $(0.8 \mu \mathrm{m}$ and $1.25 \mu \mathrm{m})$ were utilized in the hard-turning experiments. After each experiment, each cutting tool was investigated for the wear and specific cutting lengths with a light microscope and SEM. The optimum cutting conditions that provide the lowest wear rate and the longest tool life were determined with the Taguchi optimization method. Thus, the aim was to develop the cutting performance of the tools for the hard turning of a cast-iron material.

\section{TAGUCHI METHOD}

The Taguchi method, developed by Dr. Genichi Taguchi, is a technique to determine the optimum combinations of the process conditions widely used in engineering and manufacturing industry. This method is also a powerful tool for improving and designing high-quality systems. Therefore, industries are able to reduce the time of the product development without increasing the costs. ${ }^{30}$

The Taguchi method is divided into three categories: the system design, the parameter design and the tolerance design. Among these, the parameter design is the most important and used category for improving the performance characteristics without increasing the costs. The Taguchi method solves the problems by integrating the orthogonal array design, the signal to noise $(S / N)$ ratio and the analysis of variance (ANOVA). The orthogonal array is used to create a special design determining the whole parameter space with a small number of experiments. The $S / N$ ratio is employed to analyze the experimental results obtained from the orthogonal array design. The $S / N$ ratio has three performance characteristics, in Equation (1) to (3) to obtain the optimum process conditions: the smaller-the-better $(S / N)_{\mathrm{SB}}$, the larger-the-better $(S / N)_{\mathrm{LB}}$ and the nominal-the-best $(S / N)_{\mathrm{NB}}$. ANOVA is applied to identify which process conditions significantly affect the performance characteristics. A confirmation test was conducted to verify the accuracy and efficiency of the desired values achieved for the optimum process conditions: $:^{31-33}$

$$
\begin{aligned}
& S / N_{S B}=\eta=-10 \lg \left[\frac{1}{n} \sum_{i=1}^{n} y_{i}^{2}\right] \\
& S / N_{L B}=\eta=-10 \lg \left[\frac{1}{n} \sum_{i=1}^{n} \frac{1}{y_{i}^{2}}\right\rceil \\
& S / N_{N B}=\eta=10 \lg \left\lceil\frac{\bar{y}}{s^{2} y}\right\rfloor
\end{aligned}
$$

where $y_{i}$ is the observed value from the experiments, $\bar{y}$ is the average of the observed values from the experiments, $n$ is the number of the experiments and $s^{2} y$ is the variance of $y$. The steps required for applying the Taguchi method are illustrated in Figure 1.

\section{EXPERIMENTAL PROCEDURE}

\subsection{Materials}

Cast irons are called low-alloy cast-iron materials (36-55 HRC) if the amount of carbon is below $4 \%$ or high-alloy cast-iron materials (47-65 HRC) if this 


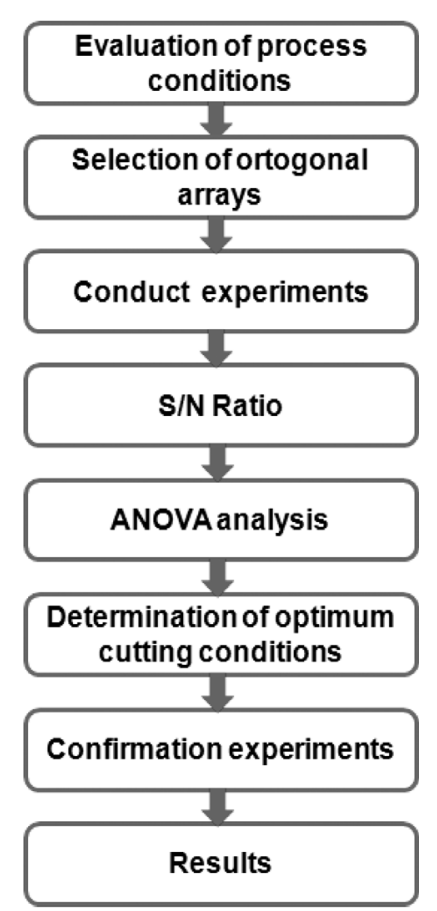

Figure 1: Application of the Taguchi method Slika 1: Uporaba Taguchi metode

amount is above $4 \% .^{4}$ In this study, the Ni-Hard 4 material, a high-alloy cast iron, is used to perform the turning experiments. It is a commercial name of highalloy white cast iron, which has a high wear resistance (58-65 HRC). Its microstructure mainly includes $\mathrm{M}_{7} \mathrm{C}_{3}$ type $(\mathrm{M}=\mathrm{Fe}, \mathrm{Cr})$ carbides and a martensitic matrix (Figure 2). It can be used in the as-cast form or after having been hardened and tempered with heat treatments. In this

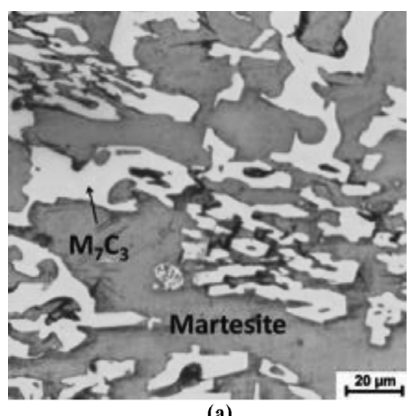

(a)

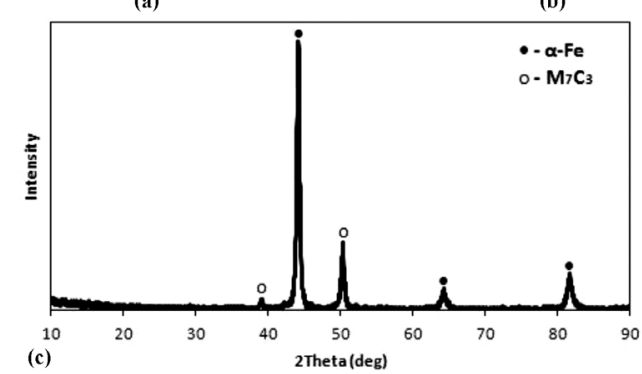

Figure 2: Light and SEM micrographs and XRD analysis of Ni-Hard 4 material

Slika 2: Svetlobni in SEM-posnetek ter XRD analiza materiala Ni-Hard 4 study, the material was used in the as-cast condition. This material is used in the as-cast condition in the cement and machine industries as well as in the mining sector. ${ }^{4}$ The material was melted and alloyed in a high-frequency induction furnace with a neutral pot and poured in a sand mold with a cylindrical form and solidification dimensions of $\varnothing 40 \mathrm{~mm} \times 120 \mathrm{~mm}$. The chemical composition of the cast material is given in Table 1.

Table 1: Chemical composition of Ni-Hard 4 alloy (in mass fractions, $w / \%)$

Tabela 1: Kemijska sestava zlitine Ni-Hard 4 (v masnih deležih, w/\%)

\begin{tabular}{|c|c|c|}
\hline Elements & ASTM A 532 & Ni-Hard 4 (sample) \\
\hline Carbon (C) & $2.6-3.2$ & 2.89 \\
\hline Silicon (Si) & $1.8-2$ & 1.43 \\
\hline Chrome (Cr) & $7-11$ & 9.22 \\
\hline Nickel (Ni) & $4.5-6.5$ & 6.15 \\
\hline Molybdenum (Mo) & $0-0.4$ & 1.03 \\
\hline Manganese (Mn) & $0.4-0.6$ & 0.91 \\
\hline Phosphor (P) & max. 0.06 & 0.25 \\
\hline Sulfur (S) & max. 0.10 & 0.16 \\
\hline Iron (Fe) & Balance & Balance \\
\hline
\end{tabular}

The cross-section of the machined material was prepared for microstructural examinations. It was etched with the Beraha II solution for about $5 \mathrm{~s}$ and then examined with a Zeiss light microscope and a Jeol JSM 6060 SEM as illustrated in Figures 2a and $\mathbf{2 b}$. The components of the microstructure were determined with a RigakuSA HS3 XRD diffractometer. The XRD analysis result is given in Figure 2c.

The microstructure of the Ni-Hard 4 material consists of a martensitic matrix and $\mathrm{M}_{7} \mathrm{C}_{3}$ primary-eutectic carbides (Table 2). The primary-carbide rate in the microstructure was estimated to be about $20 \%$. The hardness of the material was measured as $55 \mathrm{HRC}$ with a Zwick/ ZHR instrument.

Table 2: EDX microanalysis results for points 1 and 2, (in mass fractions, $w / \%$ )

Tabela 2: Rezultati EDX-mikroanalize za točki 1 in 2 (v masnih deležih, $w / \%$ )

\begin{tabular}{|l|c|c|c|c|c|c|c|}
\hline \multicolumn{1}{|c|}{ Analysis } & $\mathrm{C}$ & $\mathrm{Si}$ & $\mathrm{Cr}$ & $\mathrm{Fe}$ & $\mathrm{Ni}$ & $\mathrm{Mo}$ & $\mathrm{W}$ \\
\hline $1-\left(\mathrm{M}_{7} \mathrm{C}_{3}\right)$ & 4.3 & - & 28.7 & 66.9 & - & - & - \\
\hline $2-$ (Martensite $)$ & 1.6 & 1.9 & 4.0 & 82.7 & 5.6 & 1.9 & 2.1 \\
\hline
\end{tabular}

\subsection{Cutting conditions}

A series of 18 hard-turning experiments based on the Taguchi $\mathrm{L}_{9}$ orthogonal array design were carried out on the Ni-Hard 4 material using nine different tools without the cutting fluid. Initially, cutting conditions were selected on the basis of the user experience and tool catalogues. In this study, the speed $(n)$, the chip thickness $\left(h_{\mathrm{ex}}\right)$ and the feed rate $\left(V_{\mathrm{f}}\right)$ were calculated with Equation (4) to (6) utilizing the cutting conditions shown in Table 3: 
D. KIR et al.: DETERMINATION OF THE CUTTING-TOOL PERFORMANCE OF HIGH-ALLOYED ...

$$
\begin{gathered}
n=\frac{1000 V_{\mathrm{c}}}{\pi D_{\mathrm{c}}} \\
h_{\mathrm{ex}}=f_{\mathrm{n}} x \sin K_{\mathrm{r}} \\
V_{\mathrm{f}}=f_{\mathrm{n}} x n
\end{gathered}
$$

where;

$n=$ spindle speed, $(\mathrm{rev} / \mathrm{min})$

$D_{\mathrm{c}}=$ workpiece diameter, $(\mathrm{mm})$

$V_{\mathrm{c}}=$ cutting speed, $(\mathrm{m} / \mathrm{min})$

$f_{\mathrm{n}}=$ feed rate, $(\mathrm{mm} / \mathrm{rev})$

$K_{r}=$ entering angle, $\left(45^{\circ}\right)$

$h_{\mathrm{ex}}=$ maximum chip thickness, (mm)

$a_{\mathrm{p}}=$ depth of cut, (mm)

Nine experiments were performed for each cutting tool (Table 3) and the wear of the cutting tools was examined with a light microscope and SEM. In addition, the performances of the cutting tools were examined in terms of the powder-grain size. In these experiments, a Johnford CNC turning machine, $3500 \mathrm{~min}^{-1}, 12.5 \mathrm{~kW}$, with a feed rate of $2500 \mathrm{~mm} / \mathrm{min}$ was employed. Figure 3 shows four different steps applied during the hard-turning experiments.

Table 3: Hard-turning process parameters

Tabela 3: Parametri procesa trdega struženja

\begin{tabular}{|c|c|c|c|}
\hline \multirow{2}{*}{ Levels } & \multicolumn{3}{|c|}{ Cutting conditions } \\
\cline { 2 - 4 } & $V_{\mathrm{c}}(\mathrm{m} / \mathrm{min})$ & $f_{\mathrm{n}}(\mathrm{mm} / \mathrm{rev})$ & $a_{\mathrm{p}}(\mathrm{mm})$ \\
\hline 1 & 100 & 0.05 & 0.1 \\
\hline 2 & 150 & 0.075 & 0.2 \\
\hline 3 & 200 & 0.1 & 0.3 \\
\hline
\end{tabular}

Table 4: Cutting tools for turning experiments

Tabela 4: Rezalna orodja za preizkus struženja

\begin{tabular}{|c|c|c|}
\hline \multirow{2}{*}{$\begin{array}{c}\text { Cutting tools } \\
\text { (Uncoated) }\end{array}$} & \multicolumn{2}{|c|}{ Tool code } \\
\cline { 2 - 3 } & BS 710 & BS 610 \\
\hline Grain size (WC) & $(0.8 \mu \mathrm{m})$ & $(1.25 \mu \mathrm{m})$ \\
\hline
\end{tabular}
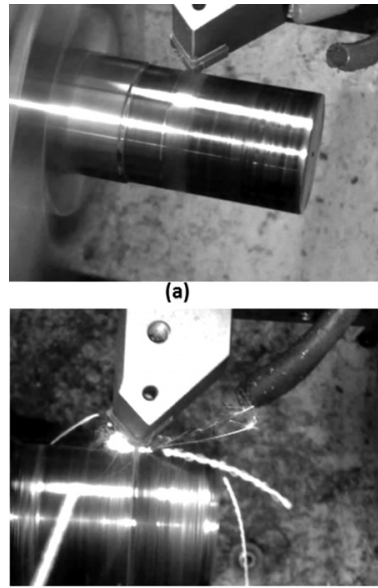

(c)
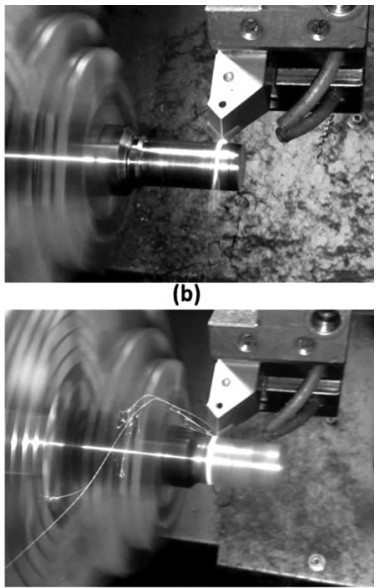

(d)
Figure 3: Hard-turning experiments Slika 3: Preizkusi trdega struženja
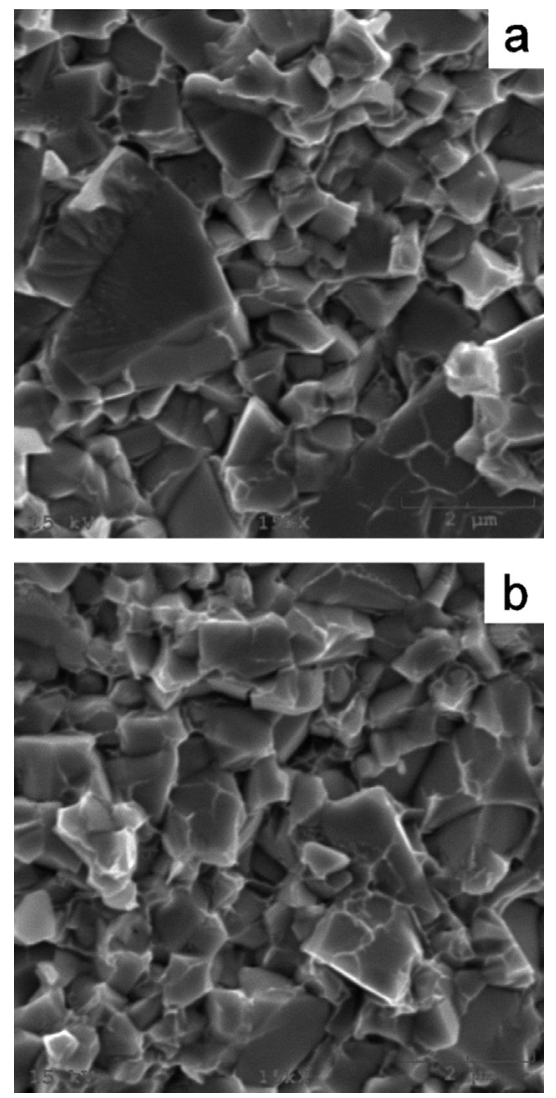

Figure 4: SEM comparison of grain sizes for cutting tools: a) BS 610, b) BS 710

Slika 4: SEM-primerjava velikosti zrn rezalnih orodij: a) BS 610, b) BS 710

The cutting tools given in Table $\mathbf{4}$ are hard-metal tools with two different WC grain sizes, sintered with cobalt (Co), (94\% WC and $6 \% \mathrm{Co}$ ). These tools were broken to observe the grain-size distributions and bonding characteristic between WC and Co. Broken surfaces were examined at a single magnification as shown in Figures $4 \mathbf{a}$ and $\mathbf{4 b}$. Figure 4 shows that the cutting tool with fine grains $(0.8 \mu \mathrm{m})$ is more homogenous than the one with coarse grains $(1.25 \mu \mathrm{m})$. In addition, the porosity rate between the WC grains in Figure $\mathbf{4 a}$ is higher than the one in Figure 4b. Cutting-tool manufacturers usually use a certain amount $(5 \%-10 \%)$ of course grains added to fine grains to improve the cutting-tool performance. ${ }^{13,14}$

\subsection{Wear measurement of the cutting tools}

The wear was investigated with a light microscope and SEM after each experiment planned with the $\mathrm{L}_{9}$ orthogonal array design by stopping the CNC turning machine at $(250,500,750$ and 1000) $\mathrm{mm}$. The numerical value of the wear rate was calculated using the CLEMEX program equipped with a light microscope. The wear rate was not allowed to exceed $V_{\mathrm{B}}=0.6 \mathrm{~mm}$ in accordance with the ISO standards. Moreover, the wear rate for the largest cutting length $(1000 \mathrm{~mm})$ and the 


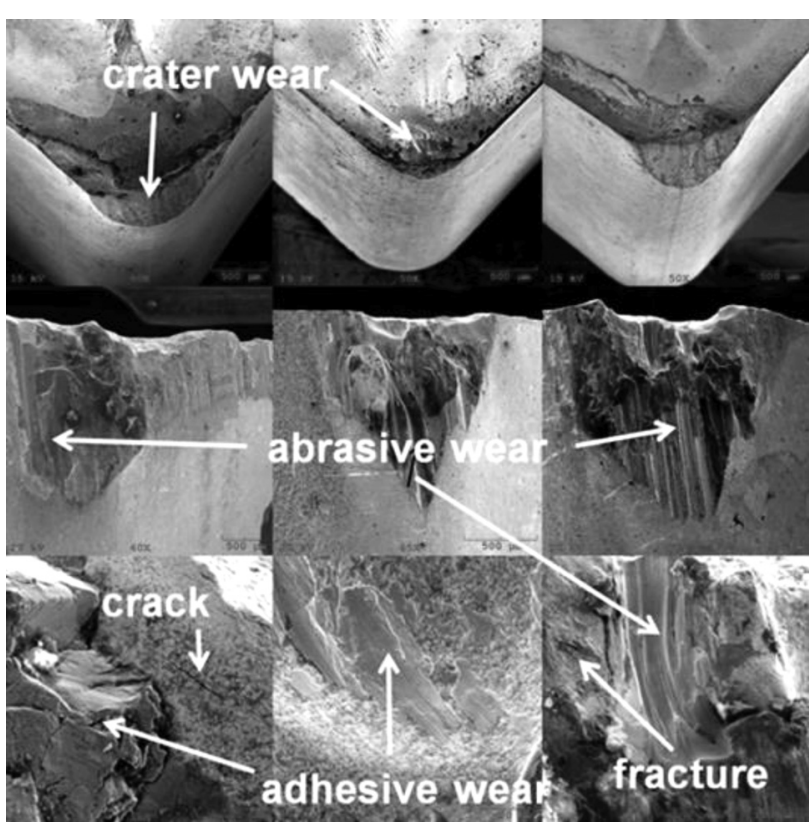

Figure 5: SEM micrographs of wear surfaces (BS 710)

Slika 5: SEM-posnetki obrabe na površini (BS 710)

shortest tool life were used to determine the optimum cutting conditions with the Taguchi optimization method.

The tool wear at the edges of the BS 610 and BS 710 cutting tools for a depth of cut of $(0.1-0.2-0.3) \mathrm{mm}$, at a cutting speed of $100 \mathrm{~m} / \mathrm{min}$ and a cutting length of $250 \mathrm{~mm}$ is shown in Figures 5 and 6, respectively. The abrasive wear increases as the depth of cut increases. Also, it can be observed that some material is adhered to the cutting edge (the adhesive wear) throughout the hard-turning experiments. In addition, some partial fractures and micro-cracks occurred due to the forces

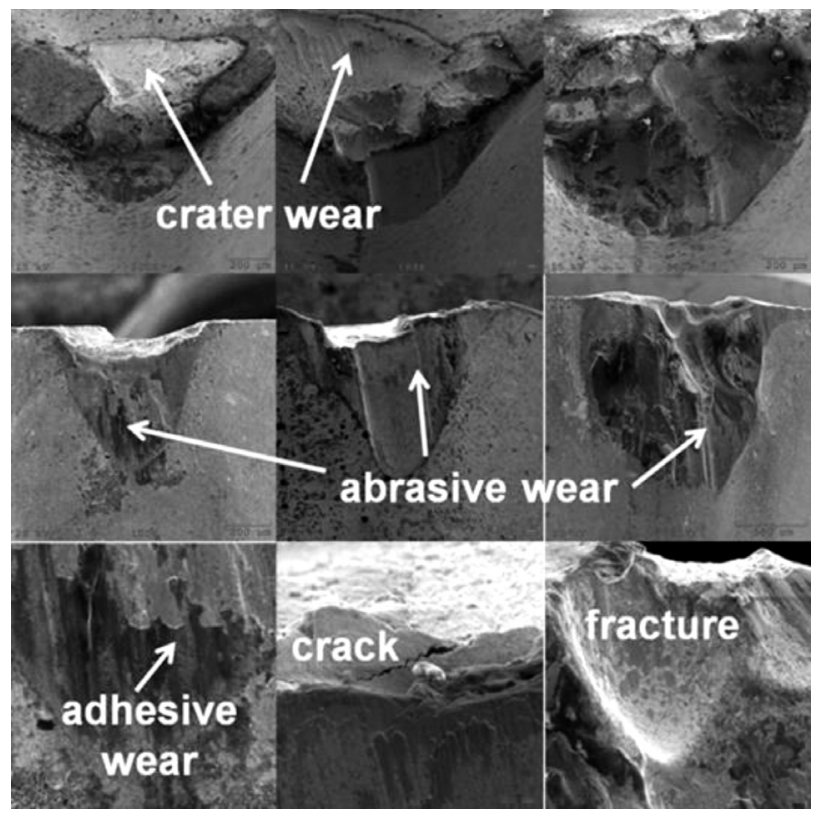

Figure 6: SEM micrographs of wear surfaces (BS 610)

Slika 6: SEM-posnetki obrabe na površini (BS 610)

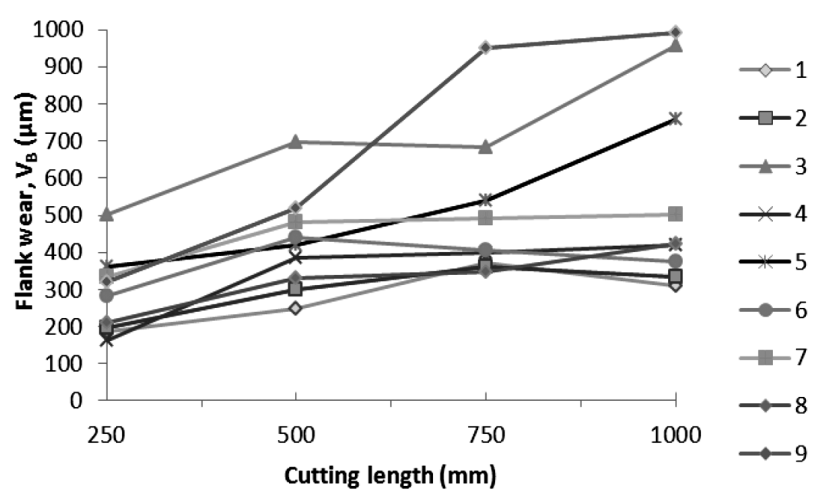

Figure 7: Change in the wear rate versus the cutting length (BS 710) Slika 7: Sprememba hitrosti obrabe $\mathrm{v}$ odvisnosti od dolžine rezanja (BS 710)

affecting the cutting edge. These failures indicate that the cutting tool was forced considerably during the hardturning process.

\section{ANALYSIS OF EXPERIMENTAL RESULTS AND DISCUSSION}

\subsection{Wear and tool life}

Figure 7 displays the flank-wear values obtained with nine experiments conducted with the BS 710 cutting tool. In Figure 7, the smallest flank wear is obtained for experiment $1\left(V_{\mathrm{c}}=100 \mathrm{~m} / \mathrm{min}, f_{\mathrm{n}}=0.05 \mathrm{~mm} / \mathrm{rev}, a_{\mathrm{p}}=\right.$ $0.1 \mathrm{~mm}$ ) whereas the largest flank wear is observed for experiment $3\left(V_{\mathrm{c}}=200 \mathrm{~m} / \mathrm{min}, f_{\mathrm{n}}=0.05 \mathrm{~mm} / \mathrm{rev}, a_{\mathrm{p}}=0.3\right.$ $\mathrm{mm})$.

Figure 8 illustrates the flank-wear values obtained with nine experiments conducted with the BS 610 cutting tool. In Figure 8, the smallest flank wear is obtained for experiment $8\left(V_{\mathrm{c}}=150 \mathrm{~m} / \mathrm{min}, f_{\mathrm{n}}=0.1 \mathrm{~mm} / \mathrm{rev}, a_{\mathrm{p}}=\right.$ $0.1 \mathrm{~mm}$ ) whereas the largest flank wear is observed for experiment $3\left(V_{\mathrm{c}}=200 \mathrm{~m} / \mathrm{min}, f_{\mathrm{n}}=0.05 \mathrm{~mm} / \mathrm{rev}, a_{\mathrm{p}}=\right.$ $0.3)$. It can be seen that the flank wear of each type of the cutting tools generally increases with the increasing cutting length. On the other hand, for experiment 1 , the

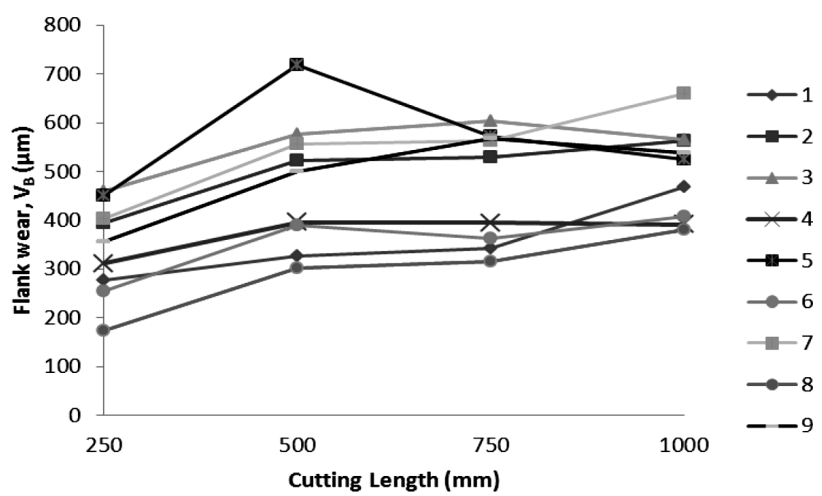

Figure 8: Change in the wear rate versus the cutting length (BS 610) Slika 8: Sprememba hitrosti obrabe $v$ odvisnosti od dolžine rezanja (BS 610) 
flank wear of the BS 610 cutting tool is greater than that of the BS 710 cutting tool.

\subsection{Taguchi analysis}

The Taguchi method integrates orthogonal arrays, the $S / N$ ratio and ANOVA to analyze and evaluate numerical results. ${ }^{29-32}$ The hard-turning experiments were performed according to $\mathrm{L}_{9}\left(3^{3}\right)$ orthogonal arrays. $\mathrm{L}_{9}\left(3^{3}\right)$ has 9 rows corresponding to the number of hard-turning experiments ( 8 degrees of freedom) with 8 columns at three levels. The hard-turning experiments based on the Taguchi orthogonal array design were conducted by means of three cutting conditions, namely, the cutting speed $\left(V_{\mathrm{c}}\right)$, the feed $\left(f_{\mathrm{n}}\right)$ and the depth of cut $\left(a_{\mathrm{p}}\right)$. The wear values obtained with the experiments and their $S / N$ ratios calculated with Equation (1) for each of the two cutting tools (BS 710 and BS 610) are given in Table 5.

Table 5: $S / N$ ratios for the wear values

Tabela 5: Razmerje $S / N$ pri vrednosti obrabe

\begin{tabular}{|c|c|c|c|c|}
\hline \multirow{2}{*}{$\begin{array}{c}\text { Experiment } \\
\text { number }\end{array}$} & \multicolumn{2}{|c|}{ Wear results $(\mu \mathrm{m})$} & \multicolumn{2}{c|}{$S / N$ ratios $(\mathrm{dB})$} \\
\cline { 2 - 5 } & $(\mathrm{BS} 710)$ & $(\mathrm{BS} 610)$ & $(\mathrm{BS} 710)$ & $(\mathrm{BS} 610)$ \\
\hline 1 & 188.2 & 276.6 & -45.49 & -48.84 \\
\hline 2 & 197.2 & 394.1 & -45.90 & -51.91 \\
\hline 3 & 501.3 & 459.7 & -54.0 & -53.25 \\
\hline 4 & 163.7 & 311.4 & -44.28 & -49.87 \\
\hline 5 & 361.6 & 449.4 & -51.16 & -53.05 \\
\hline 6 & 284.0 & 255.5 & -49.07 & -48.15 \\
\hline 7 & 332.5 & 402.1 & -50.44 & -52.09 \\
\hline 8 & 211.6 & 174.5 & -46.51 & -44.84 \\
\hline 9 & 319.4 & 355.9 & -50.09 & -51.03 \\
\hline
\end{tabular}

In order to determine the optimum turning conditions providing the smallest wear value, it is required to calculate the average-response values for the cutting conditions at different levels. For this purpose, an average-response table involving the wear values and their $S / N$ ratios is created in Table 6. The values in the average-response table are calculated by averaging the $S / N$ ratios for each cutting condition at different levels for experiments 1 to 9.

Table 6: Average-response table for the wear values

Tabela 6: Tabela povprečnega odgovora pri vrednosti obrabe

\begin{tabular}{|c|c|c|c|c|c|c|}
\hline \multirow{2}{*}{$\begin{array}{c}\text { Cutting } \\
\text { condi- }\end{array}$} & \multicolumn{6}{|c|}{ Parameter levels } \\
\cline { 2 - 7 } tions & \multicolumn{3}{|c|}{ BS 710 } & \multicolumn{3}{c|}{ BS 610 } \\
\hline$V_{c}$ & -46.74 & -47.86 & -51.05 & -50.26 & -49.93 & -50.81 \\
\hline$f_{\mathrm{n}}$ & -48.46 & -48.17 & -49.01 & -51.33 & $-50,36$ & -49.32 \\
\hline$a_{\mathrm{p}}$ & -47.02 & -46.76 & -51.87 & -47.27 & -50.94 & -52.80 \\
\hline
\end{tabular}

In this study, the ANOVA was performed using Minitab to identify which three cutting conditions significantly affect the wear. ${ }^{33}$ Table 7 shows the ANOVA results for the wear. In Table 7, the statistical significance of three cutting conditions for the wear was evaluated by the F-test. The $F$-value (tabulated) at the $95 \%$ confi- dence interval controlling the three cutting conditions is $F_{0.05,2,8}=4.46$. The percentage contributions of the three cutting conditions to the wear for the two cutting tools are given in Table 6. As can be seen from this table, the most significant cutting condition is the depth of cut $\left(a_{\mathrm{p}}\right)$.

Table 7: ANOVA analysis results

Tabela 7: ANOVA analiza rezultatov

\begin{tabular}{|c|c|c|}
\hline \multirow{2}{*}{ Cutting conditions } & \multicolumn{2}{|c|}{ Percentage contribution (\%) } \\
\cline { 2 - 3 } & BS 710 & BS 610 \\
\hline$V_{\mathrm{c}}$ & 35.238 & 1.56 \\
\hline$f_{\mathrm{n}}$ & 1.13 & 9.1 \\
\hline$a_{\mathrm{p}}$ & 62.8 & 84.7 \\
\hline
\end{tabular}

The optimum cutting conditions providing the smallest wear value were determined by selecting the largest $S / N$ ratios for each cutting condition at three levels as given in Table 6. Also, the final confirmation test for the two cutting tools was carried out in the optimum cutting conditions providing the smallest wear value. Each confirmation test was repeated at least three times. The improvement rates were calculated by comparing the results of the confirmation test and the initial values in Table $\mathbf{8}$. Thus, the optimum cutting conditions providing the best cutting-tool performance were determined with the Taguchi analyses without carrying out a high number of hard-turning experiments.

Table 8: Confirmation tests

Tabela 8: Preizkusi za potrditev

\begin{tabular}{|c|c|c|c|c|c|}
\hline $\begin{array}{c}\text { Cutting } \\
\text { tools }\end{array}$ & $\begin{array}{c}\text { Optimum } \\
\text { cutting } \\
\text { conditions }\end{array}$ & $\begin{array}{c}\text { Initial } \\
\text { values } \\
(\mathrm{dB})\end{array}$ & $\begin{array}{c}\text { Calculated } \\
\text { values } \\
(\mathrm{dB})\end{array}$ & $\begin{array}{c}\text { Confirma } \\
\text { tion tests } \\
(\mathrm{dB})\end{array}$ & $\begin{array}{c}\text { Impro- } \\
\text { vements } \\
(\%)\end{array}$ \\
\hline BS 710 & $\begin{array}{c}V_{\mathrm{c}}(\mathrm{I}), f_{\mathrm{n}}(\mathrm{II}), \\
a_{\mathrm{p}}(\mathrm{II})\end{array}$ & -45.686 & -44.565 & -44.280 & 3.2 \\
\hline BS 610 & $\begin{array}{c}V_{\mathrm{c}}(\mathrm{II}), \\
f_{\mathrm{n}}(\mathrm{III}), a_{\mathrm{p}}(\mathrm{I})\end{array}$ & -50.554 & -45.853 & -46.510 & 8.7 \\
\hline
\end{tabular}

\section{CONCLUSIONS}

In this study, hard-turning experiments were conducted on the Ni-Hard 4 material utilizing two different cutting tools (BS 610 and BS 710) under dry conditions. The following results were obtained:

- The optimum cutting entering angle is selected as $K_{\mathrm{r}}$ $=45^{\circ}$ by trying a few experiments.

- During the hard-turning experiments performed with the BS 610 and BS 710 cutting tools, the wear rate on the cutting edge increases as the cutting length, the cutting depth and the cutting speed increase.

- At a cutting speed of $200 \mathrm{~m} / \mathrm{min}$, for experiments 3,6 and 9, the wear rate of the BS 710 cutting tool is larger than that of BS 610. This situation shows that, in the case of excessive force, WC coarse grains display a better performance than fine grains.

- At a low cutting speed $(100 \mathrm{~m} / \mathrm{min})$, the BS 710 cutting tool has a better performance than BS 610. For a 
longer tool life, hard turning should be performed at a low cutting speed and with fine-grain cutting tools.

- The optimum cutting conditions providing the lowest wear and the longest tool life were determined by means of the Taguchi analyses. Improvements of 3.2 $\%$ and $8.7 \%$ were obtained for both cutting tools, respectively.

- According to the ANOVA analyses, the depth of cut $\left(a_{\mathrm{p}}\right)$ is the most important turning parameter for both cutting tools.

- Finally, the machinability of the material, which is very difficult to cut and whose cutting conditions are not widely known, were examined experimentally and numerically.

- In future, the cutting forces, the tool wear and the surface texture will be investigated by measuring the cutting forces and surface roughness in turning or milling processes.

\section{Acknowledgements}

The authors would like to thank Uğur Yücel at the University of Kocaeli and ARMEKSAN, Machine Part Industry Corporation. This study was supported by the Scientific Research Project Unit of the Kocaeli University (KOU-BAP-2012/72).

\section{REFERENCES}

${ }^{1}$ G. Boothroyd, W. Knight, Fundamentals of machining and machine tools, Marcel Dekker Inc., USA 1989, 129-151

${ }^{2}$ M. Akkurt, Machine Tools, Metal cutting principles and technology, Birsen Publication, Istanbul 1985, 49-60

${ }^{3}$ W. König, G. Ackershott, R. Komanduri, H. K. Tönshoff, Machining of hard materials, Annual CIRP, 3 (1984), 417-427

${ }^{4}$ J. M. Radzikowska, Metallography and microstructures of cast iron, ASM handbook 9, ASM international, Materials Park, Ohio, USA 2006, 555-588

${ }^{5}$ R. Correa, A. Bedolla-Jacuinde, J. Zuno-Silva, E. Cardoso, I. Mejía, Effect of boron on the sliding wear of directionally solidified highchromium white irons, Wear, 267 (2009), 495-504, doi:10.1016/ j.wear.2008.11.009

${ }^{6}$ C. Xiang, L. Yanxiang, Effect of heat treatment on microstructure and mechanical properties of high boron white cast iron, Materials Science and Engineering A, 528 (2010), 770-775, doi:10.1016/ j.msea.2010.09.092

${ }^{7}$ I. Ucun, K. Aslantaş, Investigation of cutting performance of solid carbide tool in turning hardened AISI 52100 tool steel, 5th International Advanced Technology Symposium, IATS'09, Karabük, Turkey, 2009, 200-255

${ }^{8}$ Y. K. Chou, C. J. Evans, M. M. Barash, Experimental investigations on CBN turning of hardened AISI 52100 steel, Journal of Materials Processing Technology, 124 (2002), 274-283, doi:10.1016/S09240136(02)00180-2

${ }^{9}$ G. Poulachon, B. P. Bandyopadhyay, I. S. Jawahir, S. Pheulpin, E. Seguin, Wear behavior of CBN tools while turning various hardened steels, Wear, 256 (2004), 302-310, doi:10.1016/S0043-1648(03) 00414-9

${ }^{10}$ G. Poulachon, A. Moisan, I. S. Jawahir, Tool-wear mechanisms in hard turning with polycrystalline cubic boron nitride tools, Wear, 250 (2001), 576-586, doi:10.1016/S0043-1648(01)00609-3
${ }^{11}$ Y. Huang, T. G. Dawson, Tool crater wear depth modeling in CBN hard turning, Wear, 258 (2005), 1455-1461, doi:10.1016/j.wear. 2004.08.010

${ }^{12}$ Y. Huang, S. Y. Liang, Modeling of $\mathrm{CBN}$ tool crater wear in finish hard turning, International Journal of Advanced Manufacturing Technology, 24 (2004), 632-639, doi:10.1007/s00170-003-1744-5

${ }^{13}$ Y. J. Lin, A. Agrawal, Y. Fang, Wear progressions and tool life enhancement with $\mathrm{AlCrN}$ coated inserts in high-speed dry and wet steel lathing, Wear, 264 (2008), 226-234, doi:10.1016/j.wear.2007. 03.007

${ }^{14}$ S. Khrais, Y. J. Lin, Wear mechanisms and tool performance of TiAlN PVD coated inserts during machining of AISI 4140 steel, Wear, 262 (2007), 64-69, doi:10.1016/j.wear. 2006.03.052

${ }^{15}$ T. Özel, Y. Karpat, L. Figueira, J. P. Davim, Modeling of surface finish and tool flank wear in turning of AISI D2 steel with ceramic wiper inserts, Journal of Materials Processing Technology, 189 (2007), 192-198, doi:10.1016/j.jmatprotec.2007.01.021

${ }^{16}$ J. A. Arsecularatne, L. C. Zhang, C. Montross, P. Mathew, On machining of hardened AISI D2 steel with PCBN tools, Journal of Materials Processing Technology, 171 (2006), 244-252, doi:10.1016/ j.jmatprotec.2005.06.079

${ }^{17}$ J. P. Costes, Y. Guillet, G. Poulachon, M. Dessoly, Tool-life and wear mechanisms of CBN tools in machining of Inconel 718, International Journal of Machine Tools and Manufacture, 47 (2007), 1081-1087, doi:10.1016/j.ijmachtools.2006.09.031

${ }^{18} \mathrm{~S}$. Thamizhmanii, S. Hasan, Analyses of roughness, forces and wear in gray cast iron, Journal of Achievements in Materials and Manufacturing Engineering, 17 (2006), 401-404

${ }^{19}$ R. Yiğit, F. Findik, E. Çelik, Performance of multilayer coated carbide tools when turning cast iron, Turkish Journal of Engineering and Environmental Sciences, 33 (2009), 147-157, doi:10.3906/muh0904-6

${ }^{20}$ Y. Şahin, Comparison of tool life between ceramic and cubic boron nitride $(\mathrm{CBN})$ cutting tools when machining hardened steels, Journal of Materials Processing Technology, 209 (2009), 3478-3489, doi:10.1016/j.jmatprotec.2008.08.016

${ }^{21}$ W. H. Yang, Y. S. Tarng, Design optimization of cutting parameters for turning operations based on the Taguchi method, Journal of Materials Processing Technology, 84 (1998), 122-129, doi:10.1016/ S0924-0136(98)00079-X

${ }^{22}$ A. Hasçalik, U. Çaydaş, Optimization of turning parameters for surface roughness and tool life based on the Taguchi method, International Journal of Advanced Manufacturing Technology, 38 (2008), 896-903, doi:10.1007/s00170-007-1147-0

${ }^{23}$ B. L. Gopalsamy, B. Mondal, S. Ghosh, Optimisation of machining parameters for hard machining: Grey relational theory approach and ANOVA, International Journal of Advanced Manufacturing Technology, 45 (2009), 1068-1086, doi:10.1007/s00170-009-2054-3

${ }^{24}$ J. Zhou, M. Andersson, Effects of lubricant condition and tool wear in hard turning of novel-abrasion-resistance (N-AR) cast iron, Materials and Manufacturing Processes, 22 (2007), 865-870, doi:10.1080/ 10426910701448925

${ }^{25}$ E. Sayit, K. Aslantas, A. Çiçek, Tool wear mechanism in interrupted cutting conditions, Materials and Manufacturing Processes, 24 (2009), 476-483, doi:10.1080/10426910802714423

${ }^{26}$ E. Yücel, M. Günay, Modeling of cutting force when turning highalloyed white cast irons (Ni-Hard 4), 3rd National Metal Cutting Symposium, Ankara, Turkey, 2012, 489-495

${ }^{27}$ M. Günay, E. Yücel, Application of Taguchi method for determining optimum surface roughness in turning of high-alloy white cast iron, Measurement, 46 (2013), 913-919, doi:10.1016/j.measurement. 2012.10.013

${ }^{28}$ E. Yücel, M. Günay, Modelling and optimization of the cutting conditions in hard turning of high alloy white cast iron (Ni-Hard 4), Journal of Mechanical Engineering Science, 227 (2013), 2280-2290, doi:10.1177/0954406212471755 
D. KIR et al.: DETERMINATION OF THE CUTTING-TOOL PERFORMANCE OF HIGH-ALLOYED ...

${ }^{29}$ H. Öktem, Optimum process conditions on shrinkage of an injectedmolded part of DVD-ROM cover using Taguchi robust method, International Journal of Advanced Manufacturing Technology, 61 (2012), 519-528, doi:10.1007/s00170-011-3750-3

${ }^{30} \mathrm{G}$. Taguchi, Introduction to quality engineering, Asian Productivity Organization, Tokyo 1986

${ }^{31}$ G. Taguchi, S. Chowdhury, S. Taguchi, Robust engineering, $1^{\text {st }}$ Ed., McGraw-Hill, New York, USA 2000

${ }^{32}$ W. Yuin, W. Alan, Taguchi methods for robust design, $1^{\text {st }}$ Ed., ASME Press, New York 2000

${ }^{33}$ Minitab User Manual, Release 15, Making data analysis easier, Minitab Corp., McGraw-Hill Companies, Massachusetts, USA 2007 